ties to a limited audience selected for their international repute in this field. The communications were followed by informative discussions which are included in detail.

Since the r 940 s there has been a great revival of interest in the purines which had declined since the early work of Emil Fischer some 50 years ago. During 1956 this revival has culminated in the firm establishment of the biosynthesis of purines, so that the date of the symposium was most opportune.

Alongside the remarkable advances in purine synthesis, which will undoubtedly be of great future importance in the study of virus diseases and the problem of cancer, are accounts of more direct medical interest on the purine analogues of vitamin $B_{12}$, the trypanocidal and anti-tumour activity of puromycin, and the effects of 6-mercaptopurine and its use in the treatment of leukaemia. Although this book will undoubtedly appeal mostly to chemists and biochemists, there is much in its contents which will be of interest to pharmacologists and those concerned with the academic subjects of medicine.

D.V.P.

\section{MODERN OPERATIVE SURGERY Volume II}

Edited by the late G. Grey Turner, LL.D., D.Ch., M.S., F.R.C.S., F.R.C.S.E., F.R.A.C.S., F.A.C.S., and LAMBERT CHARLES ROgers, V.R.D., M.D., M.Sc., F.R.C.S., F.R.C.S.E., F.R.A.C.S., F.A.C.S. 4th edition. Pp. xii + I 383 , with rogo illustrations. London: Cassell \& Co. Ltd. I 956 . 75 s.

Volume II completes this survey of the "whole range of modern surgical operations' and therefore includes chapters on E.N.T., ophthalmological and gynaecological operations. The object has been fully achieved and certainly all the common operations as performed in this country are described. This is done in a clear, logical and therefore interesting way by ' building up' the descriptions of the operative procedures from general principles derived from the anatomy, physiology and pathology of the part under consideration, before describing the actual techniques. 'Modern Operative Surgery' has always been a popular textbook and these two volumes maintain this excellent tradition.

It is difficult to select particular sections for praise as the standard is uniformly high and criticisms are few and only of details. The chapter on herniae is full of the basic principles and sound advice which one expects from the late Grey Turner. The drawings of the rectum and anal canal are particularly clear and useful. The transfrontal approach is rightly given pride of place over the transsphenoidal route for hypophysectomy, but its use in the treatment of advanced malignant disease might have been expanded on. Many will disagree with the view expressed that Hashimoto's and Riedel's diseases of the thyroid are variations of the same process, as the evidence against this view is rather strong. One was pleased to see the anterior approach for cervical sympathectomy emphatically recommended and the modern theory for failures or relapses strongly given.

Grey Turner's 'Modern Operative Surgery' remains a standard textbook for many postgraduate students and practising surgeons.

G.J.

\section{CHEMOSURGERY IN CANCER, GANGRENE AND INFECTIONS}

By F. E. Moнs, B.Sc., M.D. Pp. xvii + 305, with 225 illustrations. Oxford: Blackwell Scientific Publications Ltd. 1956. $£_{5} 2 \mathrm{~s} .6 \mathrm{~d}$.

Chemosurgery is the removal of tissue, such as malignant, gangrenous or infected tissue, after it has been fixed by chemical means. In the treatment of external cancer, the purpose of chemical fixation in situ is to facilitate the systematic microscopical control of excision through the use of frozen sections.

The fixative chemical used is zinc chloride in a ' permeant' base of stibnite and an 'agglutinant 8 obtained from plant extracts. This is called Z-ro8 by the author, who is Professor of Chemosurgery in Wisconsin, U.S.A.

The technique consists in excising the carcinoma surgically in a very limited way, and then applying the fixative paste for a length of time dependent upon the depth of penetration required; this fixed tissue is then excised and frozen sections of the under surface of this are then examined; further applications of the paste followed by further excision are continued until the excision is microscopically clear of growth. By limiting the application of the fixative to the cancerous areas, selective destruction of the neoplasm is possible, thus allowing greater conservatism than in more orthodox methods of treatment. The local lymph nodes are removed surgically, if they are thought to contain growth. The treatment may take eight hours and is performed under local anaesthesia.

The indication is mostly for skin carcinomata, squamous-cell or basal-cell, and five-year cure rates of over 84 per cent. and 98 per cent. respectively are claimed, but the calculation of these figures is not altogether clear. The main advantage of the method lies in its conservatism, but the results are probably no better than those from the more normal methods, which are less time-consuming.

The author also advocates chemosurgery in the treatment of benign and pre-cancerous lesions, for certain inflammatory processes and for gangrene.

Those engaged in the treatment of cancer will be interested to read this very well-presented book.

G.J. 